\title{
UNIVERSITYOF
}

FORWARD

THINKING

WESTMINSTER用

WestminsterResearch

http://www.westminster.ac.uk/westminsterresearch

\section{Environmental Renaissance Studies}

Jones, $\mathbf{G}$.

This is the peer reviewed version of the following article: Jones, G. (2017) Environmental Renaissance Studies. Literature Compass, 14 (10), p. e12407, which has been published in final form at https://dx.doi.org/10.1111/lic3.12407.

This article may be used for non-commercial purposes in accordance with Wiley Terms and Conditions for Self-Archiving.

The WestminsterResearch online digital archive at the University of Westminster aims to make the research output of the University available to a wider audience. Copyright and Moral Rights remain with the authors and/or copyright owners.

Whilst further distribution of specific materials from within this archive is forbidden, you may freely distribute the URL of WestminsterResearch: ((http://westminsterresearch.wmin.ac.uk/)).

In case of abuse or copyright appearing without permission e-mail repository@westminster.ac.uk 
Environmental Renaissance Studies

\section{Abstract}

Recent developments in renaissance and early modern ecocriticism, since surveys by Karen Raber and Sharon O'Dair, have made the field discursive. Some critics maintain that ecocriticism, ecostudies or environmental studies must be self-consciously activist and presentist. Others practise a more historicist approach, which is only implicitly activist, if at all. This article considers the recent environmental criticism of renaissance literature and Shakespeare - in its place on the spectrum of presentism and historicism and argues that the field's discursiveness is a positive development which will lead to a growth of ecocritical work in the period. Recent relevant work in environmental history is introduced, and a case made for a greater engagement with it in literary ecocriticism.

\section{Environmental Renaissance Studies}

Since Karen Raber's thorough survey of Renaissance ecocriticism was published in 2007, and Sharon O'Dair's account of Shakespearean ecocriticism followed it in 2008, the critical attention devoted to environmental studies of the period has sharply increased. In this essay, I will concentrate on the material in the field that has been published since Raber and O'Dair took stock. The model normally used to describe the development of ecocriticism - the sequence of waves suggested by Lawrence Buell - is not appropriate for renaissance environmental studies, given that the early modern period was all but ignored by the first wave. ${ }^{1}$ Diane McColley's work is an exception to this, with Milton's Eve (1983) the first of several studies that offer an ecological approach to Milton criticism (see Wilcher). Despite its slow start elsewhere, though, ecocriticism of early modern literature and drama has proliferated, and this is evidenced by the increased frequency of special issues and edited collections. Inevitably, perhaps, Shakespeare exerts a gravitational pull, with Ecocritical Shakespeare (eds. Bruckner and Brayton) appearing in 2008, a special issue of Shakespeare Studies in 2011 and a forthcoming Shakespeare Jahrbuch on 'Shakespeare's Green Worlds' to arrive in 2017. Yet other authors are not ignored: Early Modern Ecostudies (Hallock, Kamps and Raber, 2008), The Indistinct Human in Renaissance Literature (Feerick and Nardizzi, 2012), Ecological Approaches to Early Modern English Texts (Munroe, Geisweidt and Bruckner, 2015), and the special issue of the Early Modern Studies Journal (vol. 3) all explore a wide range. However, as we will see, whilst 
early modern ecostudies is an animated area of research, it is a discursive one. Most obviously, it is divided by presentist and historicist approaches. This debate, of course, is being contested outside of ecocriticism (see, eg DiPietro and Grady), but it is here that it is particularly marked. The divide is apparent among various ecocritical monographs, but even within the boundaries of individual edited collections and special issues there are entrenched differences in methodology. Although this is problematic for someespecially those who would prefer to see its central tenets synthesised and perhaps even formalised - I will argue that this disparity, as displayed by the most recent work, is a strength. This holds true for the explicitly activist critics who staunchly defend their presentism, and it holds true for the historicist critics for whom polemic is an afterthought, if a thought at all.

\section{Presentist Examples}

The most forthright conceptualisation of ecocriticism as presentist comes in O'Dair's 2008 essay 'Is it Shakespearean Ecocriticism if it isn't Presentist?' O'Dair gives the reader the answer straight away (no time like the present, after all): 'The short answer...is no' ('Presentist' 71). The longer answer, of course, has rather more subtlety and is carefully argued. O'Dair's presentism is one that takes to task the scientistic approach of literary critics who 'claim...to be a conduit for meanings about science' (80). Ursula Heise encapsulates the trouble: ecocriticism adheres to 'the scientific study of nature, the scholarly analysis of cultural representation, and the political struggle for more sustainable ways of inhabiting the natural world' (506). Literary critics are well practised in the middle one, and perhaps versatile enough to make worthwhile contributions to the latter, but as O'Dair points out, it is dangerous to imply that we are as capable of presenting clear and valid readings of scientific data as we are of plays and poems. What, then, are literary ecocritics to do? One answer O'Dair gives, in an earlier essay, is to help reconfigure professional practice: 'we can produce fine writings that are, if you will, hand-crafted or artisanal... indeed, like the literature we prefer to read. We can militate within the profession to broaden our definitions of scholarship, by insisting on quality and not just quantity in what we publish, by opposing the fetishization of the monograph as a bottom line for tenure, and by promoting to administrators and the public that good teaching is labor intensive and, indeed, part of scholarship' ('Slow' 23). What does this have to do with literary environmental studies? In each essay, O’Dair suggests that a conservation of resources is paramount: what ecocriticism requires is time, a resource 
increasingly scarce in the contemporary academy, in our current institutional formation' ('Presentist' 82). Ecocritical thinking, that is, is necessarily practical, and involves thinking about the mechanics of changes we can make to the present.

Another critic at the avowedly activist end of the spectrum is Simon Estok, whose 2011 monograph Ecocriticism and Shakespeare: Reading Ecophobia also seeks to set an agenda for the field. Ecocriticism is, according to Estok, 'committed to recognizing that there is a thing called ecophobia, and that racism, misogyny, homophobia, and speciesism are thoroughly interwoven with it and with each other and must eventually be looked at together' (Ecophobia 3). Thus 'ecophobia' becomes a term through which to understand what ecocriticism is, in part at least, aiming to redress: the discourse of 'contempt for the natural world' (2). It might seem ostentatious to define a field on the basis of one's own neologism. However, by conflating this new term with recognisable forms of collective hatred - forms that have been successfully engaged with in the critical discourse of the humanities - Estok implies a common cause, and an end-point and method by which to achieve it. $^{2}$

It is on the basis of his new term that Estok theorises the plays of Shakespeare, in ways that are recognisably presentist. Caliban, we are informed, is 'evidently vegetarian' (53). When queer theory is brought into play with ecocritical theory, in a reading of Coriolanus as weed, the image is Estok's, not Shakespeare's. The twining bodies of Coriolanus and Aufidius are figured as a relationship 'in... which women...clearly cannot compete' (34), before Estok introduces the metaphor: "The concept of "weed" is a socially useful construct that writes nature in terms of its utility to people...Though Coriolanus is never explicitly called a weed, effectively and symbolically he functions as one.' (36-7). Despite the presentist perspective, the book does have some argumentative strategies that employ early modern texts to contextualise the plays. The handling of them, though, is far from unproblematic. The contextual evidence for Estok's handling of Henry IV, Part 2, for example, is Thomas Tyron's $A W$ ay to Health. Tyron's pamphlet was published in 1697, over a century after Shakespeare's play was first performed (Thomas More's Utopia, for example, might have provided much rich alternative material). Nor are the positions outlined above utterly secure: Caliban's 'vegetarianism' is troubled by his willingness to 'snare the nimble marmoset' (2.2.167) even if he is giving up fishing (2.2.176); Coriolanus 
is not called a weed, but is described as having 'weeded from my [Aufidius's] heart / A root of ancient envy' (4.5.114-5). ${ }^{3}$ Estok ignores such apparent contradictions.

Estok's is a work that, perhaps, seeks not to persuade as much as to provoke - he is, after all, a self-proclaimed activist. Hence his arguments are at their strongest not when explicating the subtleties of the play-texts, but when theorising ecocritical approaches to them, and the concept of ecophobia is a rich one which will surely prove generative. But this position leaves him short of the audience his arguments might have reached. His position, expressed elsewhere, is that 'It is the activist ambitions that have differentiated us [the ecocritics] and what we seek to do from the legions of staid thematicists who muse endlessly as the world smolders to an end' ('Afterword' 240). And yet activists need to convince the uninitiated of the validity of their cause. For Estok, the uninitiated may be 'staid thematicists' but they remain a group of readers likely to be persuaded by careful close reading and well-evidenced sociocultural analysis. In doing neither of those things, Estok's book risks losing any audience he might have swayed to the cause.

It is in light of such a discrepancy that activist criticism must find the resources to develop its polemical points in ways that mainstream literary criticism is likely to find persuasive. There are examples of such work. Joanna Grossman's essay, 'Timon of Ashes' (2014), for example, has parallels with Estok's concept of ecophobia - 'hating mankind proves insufficient for Timon and his anger eventually leads to a rejection of the mammalian system as a whole' (2) - but makes its arguments with more careful and logical steps. Grossman figures Timon in a presentist way, as 'a bottomless well of resources' and argues that he 'is the medium that yields resources to humans, whether it be food or minerals' (4). Via spontaneous generation and the Great Chain of Being, Grossman concludes that Timon 'appears unable to conceive of virtually anything as an exploitable resource' (13) and that, in death, 'his body will be subjected to constant erosion.' (14) This, then, is the language of current environmental discourse, but reached through concepts that Shakespeare and his audience would have recognised. Grossman does not engage with critical theory or the presentist implications of her argument in the way that Estok does. Rather than put this down as a fault, though, or banish Grossman from the category of ecocriticism, we should be ready to think of ecocritical studies as broadly cause-collaborative: Grossman convinces while Estok provokes, and there's room, and need, for both approaches if we keep the field discursive. 
Some critics appear to argue forcefully against such discursiveness, as we have seen with O'Dair. Gabriel Egan's Shakespeare and Ecocritical Theory (2015) is another example. Egan stipulates 'that ecocriticism must be a presentist endeavour, in that it must turn its readings to account in improving of our twenty-first-century world' (43). His list of recent ecocriticism, though, includes Environmental Degradation in Jacobean Drama, in which the author, Bruce Boehrer seems consciously to avoid twenty-first-century analogies. Boehrer, indeed, worries about the practice of writing 'history by synecdoche, mistaking a single - and by no means dominant - part of the protesters' motives for the definitive whole.' (167). Egan's survey also finds space for criticism that explicitly excludes itself from ecocritical boundaries - such as Leah Knight's study - so his inclusion criteria aren't necessarily as rigid as they first appear. In part, this is a result of Egan's wider approach to presentist methodology, which he elsewhere classifies 'in its newly minted positive sense [as] the careful selection of evidence and transparent disclosure of what may be lost or distorted by the selection, which, as Presentists have pointed out, is also historical scholarship executed to the highest standards' (DiPietro and Grady 55). Such sentiments, and their inherent move towards inclusivity, are a world away from Estok's dismissal of 'the legions of staid thematicists'; if the ultimate aim of these critics is to increase the power of ecocriticism to effect meaningful sociopolitical change then surely the inclusive tone is the one more likely to gain the support of the wider academy. ${ }^{4}$

Following his introductory survey, Egan's latest book builds on the work done in his Green Shakespeare, offering a continuity of thinking that is nonetheless informed to some degree by the past decade of developments in ecological thinking. There are chapters on the various connotations of 'life', especially in the later plays, animal studies, and crowds as related to social networks. Historicists might wince at the appearance of E.M.W.

Tillyard as they did after Green Shakespeare, but there is great variety here, and anyone who found the earlier book of interest will surely appreciate Egan's return to the field to provide an overview.

\section{Middle Ground}

Critics have not wholeheartedly followed O'Dair's clamour for presentism. Ken Hiltner takes on a great range of texts in his What Else is Pastoral? (2011), and seeks a middle 
ground between historicism and presentism. In introducing his position, he figures presentism as problematic, and outlines the worry that,

as conventional wisdom holds that our present environmental crisis emerged alongside technological modernity and the so-called Industrial Revolution, ecocritics and casual readers alike are often doubtful when second-wave ecocritical approaches, such as my own, push back into the Renaissance, as these appear to be presentist projects that mistakenly see, as we say, nunc pro tunc [now for then], when then seems very different than now environmentally (3).

Hiltner's approach is not so much to locate in period the formative energies that led to 'technological modernity', but rather to argue that nunc tunc est. 'early modern England was indeed in the throes of what can only be described as a "modern" environmental crisis, which engendered a number of contemporary debates, some of which address issues of environmental justice that informed (and were informed by) both canonical and noncanonical literature of the period' (4). More recently, Hiltner has further refined his position, by offering the cogent example of Edmund Spenser's Shepheardes Calendar and its (apparent) representation of John Aylmer as Morrell. Concerned by the idea that 'we risk seeing (and, accordingly reading) the present in our environmental past, even though something very different is often written there', Hiltner focuses on Aylmer's reputation ('Reading' 30). Morell might come across as the villain of the piece in either case especially in relation to Grindal - but, Hiltner contends, 'To an early modern audience... he would have seemed reprehensible for very different reasons than he does today.' (34). The claim is based Aylmer's reputation for reckless profiteering from deforestation, set against what we might casually read as a modern environmentalist ethic. Jeffrey Theis's book (2009), meanwhile, takes on Shakespeare's plays in its first half and later seventeenth-century literature in its second. The object is to take the way in which the sylvan pastoral took and changed shape, in order to show the evolution of environmental imagination. Theis sees pastoral as a vehicle for figuring both individuality and nationhood, against the backdrop of the nation's deforestation, the English Civil War and the political reform activities of figures such as Gerrard Winstanley. He claims that Milton is engaged in 'developing [an] environmental ethic profoundly reformist and spiritual to the core' (244) and that whilst Shakespeare employs the sylvan pastoral as a performative space, 'Milton ends up rejecting the concept of the sylvan nation and supplants it with a sylvan world that is presciently postnation' (xv). Theis's work, by tracing the development of sylvan pastoral over several decades, shows how environmental relationships evolve in the cultural imagination. 
Like Terry Gifford before them, Theis and Hiltner have cleared the way for further reinvestigations into pastoral - studies that explore not only the allegorical character of the form but the will to allegorise. By locating an etiological element in pastoral, both Theis and Hiltner show that historicist readings can be brought to bear on presentist concerns

Another work adopting a mediating approach between presentism and historicism is Todd Borlik's Ecocriticism and Early Modern English Literature (2011). Borlik claims that 'Early modern ecostudies can make a positive contribution to environmentalism by resurrecting the era's understanding of nature (possessed by an anima mundi) as a quasideific force' (67). In order to do that, of course, we would have to meticulously reconstruct that understanding from our primary and archival texts: present concerns furthered by historicist work. But Borlik also argues that we can draw from 'Shakespeare, Spenser, and Sidney' 'an exceptionally nuanced understanding of the interplay between art and nature that offers a blueprint for reconciling ecological assumptions of a pure and essentialized Nature with post-structuralism's attempt to reduce the non-human world to a cultural construct' (15). That is, early modern can help us develop post-modern, as long as we are careful enough with our conceptualisation of the steps of modernity. Hence Borlik's conclusion that 'One of the particular merits of an early modern ecostudies is that it allows for surprising insights and perspectives that are...inaccessible to ecocriticism that has largely tethered itself to twentieth-century poetry and Nature writing' (207). Borlik offers the example of humoural theory, which, 'In contrast to the post-Cartesian view of the self as an impregnable, disembodied res cogitans...entails an understanding of the body and temperament as conditioned by its environment' (207). As an example of the ways in which present-inflected ecocriticism, such as Borlik's, can be read as in dialogue with a historicist study, such as Leah Knight's, see how Knight makes a similar move: 'greenness, with its connotations of lively, health-giving virtue, was imagined to enter the porous early modern body not only through the eyes but through the respiratory system' (9). Although, as we shall see, Knight is one of a group of scholars who avoid framing their work as ecocritical, it is clear here that her point adds further nuance to that made by Borlik. As for environmental studies in general, so for individual works: Borlik's pragmatic approach is enriched by its dialogic quality, and this has continued beyond his monograph. In his article 'Caliban and the Fen Demons of Lincolnshire' (2012), Borlik brings a historicist approach to the unfolding of fenland 
ecology and its associated myths, but concludes that 'In a world threatened by increasingly ferocious tempests, rising sea levels, and toxins in our water supply, Caliban's curse reads like a premonition of ecological blowback' (44). Rather than essentialise either the past's attitudes or the present's concerns, Borlik's work shows how the one influences - and can continue to influence - the other.

So too does Lynne Bruckner. In her essay on Richard II, Bruckner finds room for Thomas Tusser's Five Hundreth Points of Good Husbandry (1573) and Thomas Hill's Gardener's Labyrinth (1577) to explicate Elizabethan husbandry, and notes that the importance of productive gardening techniques... would have reverberated significantly for audiences in the 1590s (DiPietro and Grady 131). Via state papers, and through the neatly outlined concepts of good stewardship, the reader is well placed to recognise as Bruckner does Richard's failure on an environmental as well as monarchical level. But Bruckner takes the extra step, to show how the lessons of the play are a helpful frame through which to consider the similarly failed stewardship of twenty-first century fracking. The point here is that Shakespeare critics who are averse to presentist lines of argument might flinch at a phrase such as 'seven million pressurized gallons of "slick water" (water mixed with proprietary toxic chemicals) are injected into each well' in their reading, but coming as it does after Bruckner's careful historical work the logic seems not only palatable, but inevitable (143).

Randall Martin's Shakespeare and Ecology (2015) is similarly inclusive in approach. Like Borlik, Martin does not balk at carefully contextualized historical material, nor at coopting that material for presentist conclusions. So, for example, like Vin Nardizzi (see below), Martin discusses Tudor deforestation practices and how 'Heightened anxiety about the state of her forests prompted Elizabeth to take the first documented steps towards actively regenerating crown woodland' (46). Following an account of Merry Wives read along these lines, Martin concludes that the play offers 'an eco-poetic shake-up' for today's readers and audiences (54). But Martin's study is also overtly engaged in the methodological consequences of his approach. In considering Shakespeare's anachronisms, for example, he argues that 'Temporally layered history was, and remains today, a matrix of ecological understanding in Shakespeare' (80). As such we can consider the 'eclectic postmodern weaponry' of adaptations, and how stage and screen versions of the plays 'invite audiences to translate their recognition into contemporary political choices' (80). Like the rest of the work in this section, that is, Martin's book 
embraces the discursive possibilities of ecocriticism, not losing sight of present ecological concerns, but informing them with historicist approaches.

\section{Middle Sea}

As ecocriticism has grown in popularity, various sub-disciplines have developed from, or in relation to it. Animal Studies, Food Studies, Ecofeminism, Darwinian Studies and Climate Studies have all emerged in their own right, to the extent that they will be better served by separate review essays. One such school, though, deserves discussion here, for its participants share with those studies of the previous section a willingness to engage with historicist thinking. The study of literature and the environment is sometimes referred to as 'green criticism', signifying both an activist political stance and a tendency to focus on landscape, forest or wilderness. Dan Brayton and Steve Mentz have both been engaged in redressing this 'terrestrial bias' of ecocriticism (Brayton 18). Mentz has argued cogently for a 'blue cultural studies' to complement and counteract the green studies with which ecocriticism is generally associated, and it is this vein that his most recent book and that of Brayton are written (Mentz 'Blue'). In presenting the case for maritime ecocriticism, each work charts a course between historicist and presentist discourse. Mentz asserts that 'Shakespeare isn't dead. He isn't even past' (Ocean 98), but accommodates 'early modern works of hydrography and navigation' into his analysis and explication of the 'sea-fever' of Shakespeare's contemporaries (4). Brayton's study fixes as much on the material as on the metaphorical: thus, Brayton explores the relationships between the emotional human body and the tidal oceans; between royals and whales; and between the fish trade and human identity. 'At the same time that I take a presentist approach, I also find the work of marine environmental historians and the methods and insights of historicist scholarship indispensible for decoding early modern...texts' (6). ${ }^{5}$ Brayton therefore determines that 'The present condition of the global ocean argues beseechingly for a conceptual holism that is both presentist and historicist in scope' (11). When the course of the argument diverges, Brayton explicitly outlines both historicist and presentist directions, enabling the reader to see the mutually beneficial ways in which we might set sail. Take, for example, the clouds Hamlet and Polonius observe, and 'the seaward drift of Hamlet's similies.' (76) Brayton notes 'One way to construe this brief exchange is in a historicist mode, as an instance of the epistemological unavailability of the sea and its denizens to early moderns. Another is in a presentist mode: it provides a paradigm of general human ignorance about the sea.' (77). It is in such moments that 
Brayton manages to enrich both directions of discourse with the other, and, perhaps, charts a course for future ecocriticism to navigate. A further direction, of course, is to take Hamlet's 'Do you see yonder cloud...' as an invitation for the audience to look up. Brayton realises this - the joke is on them, he claims - without quite thinking through the implications. He writes that 'there is no actual cloud present to provide an ekphrastic anchor to our understanding', but that neglects the open-air theatre setting (76). It also neglects records of early performances, most obviously that in 1607 aboard the Red Dragon off the coast of Sierra Leone. How might that 'seaward drift' operate in such a stage dynamic? Ecocriticism of early modern theatre would do well to attend to the environmental irony (or aleatoric effect, as Penelope Woods has put it) integral to its performance spaces, for it is at this basic level that the texts most clearly relate to their immediate environment. ${ }^{6}$

For Mentz, meanwhile, to concentrate on the sea is to refocus the central tenets of ecocritical approaches to text:

while literary criticism can't make fresh water out of salt or protect lowlying cities from tropical storms, it's through narrative and language that our culture has always grappled with living in an unstable, oceandrenched environment. Shifting our focus from the supposed stability of land, with its pastoral and georgic master narratives, to a broader vision that embraces the maritime world... will mean abandoning certain happy fictions and replacing them with less comforting narratives... But - and this is the key point - we have these narratives already. We just don't always put them at the center where they belong. (Ocean 98).

As Mentz suggests, there remains much to be done if the recent surge in maritime humanities is successfully to be brought to bear on ecocritical discourse, not least a move towards wider-ranging studies that focus on several writers. ${ }^{7}$ As Mentz puts it, 'the story of how human meaning attaches to the oceans comprises a full history of Western culture' (Ocean 3). Mentz and Brayton have, however, provided a comprehensive framework for those about to embark.

\section{Historicism}

For those who would contest that the whole field of ecocriticism - grounded as it is in the recognition of today's environmental crisis - could be labelled pedantically by historians as presentist, there yet remains a spectrum within it. Bruce Boehrer's Environmental Degradation in Jacobean Drama (2013) proves an illustrative example. Boehrer 
claims that 'the literary modes of urban satire, pastoral escapism, and proletarian nationalism remain to this day the most powerful imaginative tools we have to confront the ongoing degradation of our natural environment' (27). In so doing, Boehrer comes close to the activist tone of some of the critics discussed above. However, when Boehrer makes a point about Ben Jonson - his 'chief environmental insight, at once simple and profound: goods decay, but trash is forever' (60) - he does not use it as a way into to discussing landfills, recycling and the Pacific trash vortex. Presentist activist critics, such as Estok or O’Dair, would surely have made such a move. Boehrer instead remains focused on the early manifestations of environmental degradation. The implications for our understanding of our own environmental crisis and the responsibilities of the humanities therein are left to the reader to infer.

Boehrer's work is also characterised by the lack of a single centre, instead being structured around six playwrights - Middleton, Jonson, Shakespeare, Fletcher, Dekker and Heywood. These writers are grouped in pairs, with the aim of contextualising each dramatist with the work of his contemporary. Boehrer's book is thereby structurally very different from most works in eco-studies. The importance of the representation of environmental degradation, according to this methodology, resides in how it situates the primary material in its immediate dramatic and biographical contexts, rather than how it relates to the concerns of the twenty-first century climate debate. It also allows Boehrer to conclude that 'In the major surviving works of the Jacobean stage, one encounters repeated references to ills and anxieties associated with the degradation of the natural world, especially the natural environment surrounding London itself (166).

One of the central figures of the surveys of Raber and O'Dair is Robert Watson, whose Back to Nature: The Green and the Real in the Late Renaissance (2006) explored the epistemological understanding of early modern human/nonhuman relations via close historicist reading. Scholars who found Watson's work useful will find a similar starting point taken by Tom MacFaul, who, unlike Watson, concentrates largely on Shakespeare and argues that 'he shows a continuing... hope that nature may have redemptive properties.' (10). MacFaul's approach, like Watson's takes full account of the complexities of early modern epistemology and the slipperiness of the concept of nature. Although both Watson and MacFaul are clearly informed by presentist ecocritical work (neither one restricted to early modern studies), they both incorporate a great deal of 
other approaches too, and neither is especially forthcoming with presentist conclusions. Since Back to Nature, however, Watson has argued specifically for an approach to ecocriticism that blends historicist and presentist thought:

Renaissance humanists recognized that studying literature was valuable partly because it allows people to take some distance on their own cultural assumptions, and apply the lost wisdom of the past to seemingly unsolvable problems of the present. So my argument that Midsummer Night's Dream can be useful in our ecological crisis is presentism with an apt historical grounding... Precisely by seeming to be just a nice little story about lovers and fairies in the forest on a moonlit summer night, this comedy can slip into our heads something it is otherwise hard to get our heads around: the fact that our insularity as individuals and as a species is a destructive illusion, an enclosure crisis of the human self. ('Ecology' 52-3)

However, Watson is also aware of the way in which this approach has been characterised in reactions to his work:

The response to my argument has been...that I am losing the urgent eco-political questions by allowing them to sublimate into epistemological questions, confusing a political project with an enervating, attenuating cognitive inquiry, and thereby $d e$-politicizing environmental science. Several reviews of Back to Nature complain that it is not really ecocriticism at all, because it neglects to advocate environmentalist policies or put its scholarship directly and unambiguously in their service. ('Shadows' 48)

The issue, then, is that Watson's work is not activist enough. If 'presentism with an apt historical grounding' looks too much like historicism, then it will fall short of the ultimate goal of ecocriticism, which is, according to the respondents, grounded in ecological praxis. However, as Watson makes clear, historicism can be practical too: 'Analyzing the forces that shaped current attitudes toward nature - which literary criticism allows us to do - offers the best chance of revealing the destructive ones as contingent and therefore dispensable' (48). Moreover, the notion that presentism is indeed the most persuasive and effective form that activist criticism might take is one that Watson problematises: 'If we neglect or even disdain to do that intellectual work in depth and in good faith, we are left with nothing but the paternalism that has already bred resentment against environmental causes.... Or have we eco-scholars not really understood the traditions and anxieties that keep people from accepting and applying what they hear?' (48). It is these traditions and anxieties, surely, that literary critics are in a strong position to identify and analyse, with the 'intellectual work' that Watson refers to, and thereby form a better platform from which to advocate ecological change in a thoroughly presentist way. ${ }^{8}$ If praxis is the ultimate goal of literary ecocriticism, both the 
historicist and presentist camps are therefore required to meet it. Instead, it may be that some scholars steer clear of claiming terms such as 'ecocriticism' or 'environmentalist reading' for their own studies in part because they have seen in the aftermath of Watson's book the way such language shapes critical reception. The responses to Watson that claim Back to Nature is 'not really ecocriticism at all' have not thought hard enough about the implications of the book's conclusions, nor how to utilise them within their own presentist methodologies, and have instead concentrated their efforts on maintaining stewardship over the field's nomenclature. Consequently Watson's work is obscured by the challenges it posed to the narrowly defined ecocriticism, when it might better have paved the way for a broader and more discursive one.

The question of praxis is also behind the approach taken by the contributors to the 2011 collection edited by Jennifer Munroe and Rebecca Laroche, Ecofeminist Approaches to Early Modernity. Again the negotiation between historicist and presentist directions comes down on the side of the former: 'to remind ourselves that early modern women's experience with non-human and human nature was necessarily shaped by the many tasks associated with their households, the house, and its environs' (5). They are keen that their collection does not do as other ecocritical discussions of the period have done: 'subsumed feminist criticism to the greater goals of ecocriticism by declaring their shared "activist motivations and intentions" without acknowledging the extent to which recent development in feminist studies (and others) can prove illuminating for ecocriticism itself (5). Munroe and Laroche conceive of ecofeminism as sharing a purpose with ecocriticism, but not as the same thing - and indeed, the field would be better treated as the subject of a different essay. However, it is worth pointing out that, rather than agree with Estok's position that the common practical purpose between the discourses is one of finding instances or utterances of oppression, whether of gender or environment, the editors here advocate a historicist approach to develop their case: 'The most promising direction...for such feminist work is in the unearthing of the presence of women in the archive and with it a focus on the materials of women's lives' (6). History provides evidence and energy toward a present cause.

In Wooden Os, his 2013 study of the relationship between early modern deforestation and the London playhouses, Vin Nardizzi seeks to '[discover] in early modern culture and literature precursors to more modern environmentalist practices and habits of thought. 
But it does not aim to celebrate them in unambiguous terms, as ecocritical scholars of early modern letters have tended to do' (28). Nardizzi, instead, pursues what he calls 'eco-materialism' - here the connection between the forest and the performance spaces they were used to construct. This Nardizzi does by exploring representations of trees and forests in plays - in particular the stage tree - in an aim to show how the theatre and its constitutive woodenness reverts to a former material condition' (23). In so doing, the book aims toward 'a fuller picture of early modern woodland ecology and its stage representations by contemplating the darker shades of green in the contested, felled, fatal, logged, and razed trees of early modern drama' (28). Nardizzi’s study thereby bears a relation with the work of Timothy Morton, whose concept of dark ecology has proven influential in ecocriticism since his Ecology Without Nature (2009). Nardizzi does not explicitly discuss the question of historicism vs. presentism, but presents an ecocriticism that is rooted in theatre history. ${ }^{9}$ If we are to take seriously Watson's suggestion that 'Our species will wither alone in the shadows of an ancient loss...unless we cast some light on the antecedent relations between human and nonhuman life,' then Wooden Os is an important work for its explication of those relations ('Shadows' 40).

So, too is Reading Green. Leah Knight frets about present-inflected ecocriticism ("now nearly, if still newly, canonical perspective', as she puts it) monopolising the study of the natural world (4). Knight worries that ecocriticism 'risks becoming the only stance available in relation to material that appears to fall within its purview' (5). In order to keep the field as wide as possible, therefore, she makes the distinction: 'this book is only an attempt to read green, not to read greenly. A claim upon the adverb would suggest a tempting but unwarranted alliance with ecocritical projects that at times align with mine but that are often - and often quite rightly - governed instead by pressing political aims and actions that I cannot claim as the motivating force or operating framework for this study.' (5). Although her motivation and framework are elsewhere, though, Knight's work still casts some of the light that Watson hopes for. So too does Charlotte Scott's Shakespeare's Nature (2014), with its detailed account of early modern husbandry.

Although Knight is at pains to point out that in the early modern period, 'the ecological as we know it was then only barely being defined as requiring human concern and action', there is, in her wariness, an important wider point (1). Just as we might frame the age as early modern we might also frame it as early ecological (if 'only barely'). The 
significance of this is not to claim some hazy problematic teleology. Rather, it is a reminder that perhaps the problems with our present ecology can be more thoroughly understood when we take a fully informed account of the various forces that early ecology competed with it in its infancy. The activist battle for an ecological sensitivity in reading texts is in part founded on the principle that such sensitivity will make us better at caring for and protecting the environment. But the sensitivity is all the greater for accounting for the intellectual and cultural milieu of the texts' production. Hence studies such as those of Nardizzi, Knight and Scott, even when they avoid activist criticism, bolster the activists' armoury, just as Watson's has done since its appearance.

\section{Environmental History}

Those embarking on a historicist approach to ecocriticism will, of course, explore the archives for appropriate material outlining and exemplifying humankind's shifting relationship with its environment. There, they will do well to find a more fitting name than that of John Manwood, whose Lawes of the Forrest (1598) deals with laws of definition and morality as well as legality. It also seeks to establish a pre-Norman ancestry of the forest in England, thus making forests part of Anglo Saxon identity. Given the forest's place in renaissance ecocriticism, and Manwood's treatment of it, the work is virtually essential reading for those entering the field. There, it sits alongside Edward Topsell's histories of animals and John Evelyn's 1661 pamphlet on air pollution, Fumifugium.

Manwood and Topsell have gained attention from historically-minded ecocriticism, for they articulate a response to the changing relationships between the human and nonhuman. But the same critics might also pay greater attention to the details of the changing relationships themselves. In order to do so, they should draw more heavily on the burgeoning discipline of environmental history, for, with some exceptions, it is an area underused in ecocritical studies. ${ }^{10}$ Overviews of the field might be rather more broad than one is accustomed to: Jan Zalasiewicz and Mark Williams, for example, call their 2012 geo-climatological study The Goldilocks Planet: The Four Billion Year Story of Earth's Climate. The field, however, is sufficiently rich for general studies to be more specific. The environmental history of the medieval period, for example, is analysed in recent monographs by John Aberth (2012) and Richard Hoffmann (2014), both chart the shifts in attitudes to the natural world over the middle ages. For the early modern period, 
however, the standard work remains John Richards' The Unending Frontier: An Environmental History of the Early Modern World (2003). Whilst its scope is huge - covering settlements in most of the world, and activity in much of the ocean, for the sixteenth, seventeenth and eighteenth centuries - the first sections are a helpful and concise overview to anyone new to the discipline. As Richards puts it, 'Environmental history is more than the sum of national environmental narratives [...] The long-term effects of human action are best seen in detail at the local level, but best understood in a holistic global perspective' (3). That perspective, in Richards' handling, is one of migration and expansion, and it is in this context that the influence of and consequences for the environment are read. Richards eventually states that 'During the early modern period, there was an irresistible, and seemingly irreversible, trend toward more intensive human control and use of the land and natural environment' (618). Whilst there have been forays into the debate since, there remains scope for studies to develop or challenge this conclusion. ${ }^{11}$

Environmental factors are increasingly foregrounded in more conventional historical narratives, such as Daniel Headrick's Power over Peoples: Technology, Environments, and Western Imperialism, 1400 to the Present (2012). As well as examining technological and social developments, Headrick takes into account the environmental influences that imperialism capitalised upon. War and colonialism, then, are recast as environmental. This is the case made by Katherine Grandjean, who argues that food shortage and other, more explicitly environmental factors were reasons for the attacks on the New England natives in the seventeenth century. Dagomar Degroot, meanwhile, considers the ways in which sea weather influenced the naval conflicts between the English and the Dutch. The consideration of environmental factors in war - especially naval war - is hardly new, but in its emphasis and explication such work offers detail and a rich sense of the relationship between environment and human history that is useful for those considering a historicist environmental approach to the literature of the period.

For the human-sea relationship in other contexts, we might consider fishing. Jeffrey Bolster covers several centuries of it - from medieval to modern - in The Mortal Sea: Fishing the Atlantic in the Age of Sail (2012). Jakobina Kirsten Arch's doctoral work concentrates on whaling in early modern Japanese culture, exploring its economic, environmental and imaginative impact. Or we could focus on floods, as the 2013 special 
issue of Environment and History does. There Tim Soens discusses North Sea flood defences in the early modern period, and Christian Rohr concentrates on the Danube from 1350 to 1600, looking at responses to and management of, its floods. James Galloway, meanwhile, gives a similar analysis, of the East coast of England in the later middle ages. Soens also offers a longer-term perspective, in his 2011 chapter, 'Threatened by Sea, Condemned by Man? Flood Risk and Environmental Inequalities along the North Sea Coast, 1200-1800', which takes in England and the Netherlands.

Natural histories are found in the doctoral research of Gail Marlow Taylor (on New

World medicinal plants') (2014) and April M. Kiser (on 'natural history images') (2011).

For histories of the weather, we can again find long-ranging studies and those of depth in detail. Jay Barnes' North Carolina's Hurricane History (2013) starts in the sixteenth century and finishes in the twenty-first, thus establishing a continuity between present environmental experience - with its meteorological data - and that of the early moderns. Such a continuity is crucial for ecocriticism's understanding of the importance of historical attitudes and their relationship to our own. In a related vein, Adriaan de Kraker (2013) examines storms in the Low Countries from 1390-1725 and compares the data with those for modern storms. Alan R. Macdonald and John McCallum (2013) argue that we can infer more accurate meteorological data from the period than we might expect, by drawing on ecclesiastical court records. They exhibit this methodology for Scotland from 1619 to 1622, when particularly severe weather disrupted court proceedings.

The above is merely a representative selection of work in early modern environmental history from the last few years. There is much more to be found in each of the areas sketched out here. ${ }^{12}$ Studies of literature and the environment would do well to take advantage of such research, whether those studies take a historicist approach or not. For without a clear and precise understanding of historical climate conditions, the human attitudes towards climate conditions, along with our grasp of their textual representation, are inherently nebulous.

\section{Conclusion}

A fundamental principle of ecocritical discourse is that the human and nonhuman are more interconnected than we generally acknowledge. Casual dips into ecocriticism 
readers and textbooks will be enough to find statistics for how many bacteria are in our guts, or what percentage of our DNA we share with daffodils, as well as the more familiar problems of $\mathrm{CO}_{2}$ emissions and plastic waste set out in the stark data of human responsibility. From the ecocritical perspective, we are made of the world, and the world is made of us; human and environment are not discrete. With this awareness of interconnectedness in mind, it is curious that some ecocritics remain suspicious of approaches that differ from their own, for surely there is an analogy in critical thought. Any research that develops and refines our understanding of early modern environmental conditions, or cultural representations of those conditions, is beneficial to the sharp end of activist presentism. This is not to suggest that historicist study is somehow scholarly in a way that presentist study is not, but that in order to work towards effecting a cultural shift in attitudes towards the environment and policy, a holistic, inclusive approach to the ecocritical perspective is necessary. This is as much a matter for historicists considering the work of presentist scholars as vice versa. Happily, archival studies have never been more open and accessible. We can have legitimate questions about the environmental impact of their servers, but digital archives allow for a great deal of historicist research to be done without needing physically to travel to the archives themselves. Such study, that is, follows in the direction O'Dair has demanded ecocritics take in considering the footprint of their own research.

Presentism is a good fit for Shakespeare, given that theatre companies persist in drawing out ways that the plays speak to our contemporary issues. It does seem curious that presentist ecocritics do not make more of Shakespearean performance - there are precedents that offer a theoretical framework (e.g. Wendy Arons and Theresa May's 2012 collection Readings in Performance and Ecology) - but work is starting to emerge. Jennifer Mae Hamilton (2012) and Evelyn O’Malley (2016) both have forthcoming monographs from their doctoral theses on the subject. Moreover Randall Martin's epilogue offers an ecocritical reading of the 2006 RSC The Tempest, Martin continued the line of inquiry at the 2016 Shakespeare Association of America meeting, with a seminar on 'Towards Ecocriticism in Performance' and, with O'Malley, is editing a forthcoming special issue of Shakespeare Bulletin titled 'Eco-Shakespeare in Performance'. Shakespearean presentist studies can perhaps engage with the work of other writers of the period in a more sustained way, and thus make a more forthright case for renaissance ecocritical presentism. But as studies such as Nardizzi's show, theatre history and environmental 
issues can successfully be read together too. These studies form part of a wider trend in renaissance environmental studies, one that reclaims and adopts historicist positions. This trend is a response to the need for ecocriticism to become cannier in the way that it persuades its readers. Without the inclusion of historicist approaches, ecocriticism is estranged from the work of critics whose arguments are pertinent to the field but who seem consciously to avoid it. Watson's argument for historical perspective is that we understand the development of attitudes 'lest we be condemned to repeat' them ('Shadow' 58). As with the methodology, so with the field itself: ecostudies must retain space for historicist studies if it is to avoid repeating the same plaintive arguments in ever more desperate ways. Without a historicist perspective, that is, ecocriticism risks becoming echo-criticism. As the work of the past few years shows, the work of historicism is crucial in furthering and enriching the field. 
I would like to thank the anonymous reviewers of this essay for their thoughtful and helpful suggestions, which have enriched my thinking greatly. I'd also like to thank Sam Solnick. Omissions are inevitable in an article such as this, but they are I acknowledge mine.

${ }^{1}$ For a succinct account of the waves of ecocriticism, see Marland. For problems with the wave model, including those noted by Buell, see Garrard 2-3.

${ }^{2}$ It is important to note that, for the purposes of this article, I have grouped activist criticism as though it were homogenous. But there are great differences of opinion especially concerning the place of theory - amongst these critics. In particular, Estok's concept of ecophobia sparked a debate now known as the 'Estok-Robisch Controversy'. See Robsich, 2009 and Mackenzie and Posthumus, 2013.

${ }^{3}$ Curiously, Estok quotes from both of these speeches - even interpreting Caliban's 'crabs' as shellfish rather than crab apples - without worrying about the ambiguities they confer on his readings of Caliban and Coriolanus. See 34 and 104. There is another feature of Estok's work that will exasperate those coming to ecocriticism from other areas of early modern drama studies: Estok misreads lines of play text in an attempt to make his activist case. For example: 'Cordelia's silence, her artless "nothing," is something "which nor our nature nor our place can bear" (1.1.171 [Estok's emphasis]). It is a subversion of authority for Lear that both nature and space repel, like the positive end of a magnet repels the negative.' (27). Estok uses this reading of Lear's line as part of the foundations for his arguments for the play's concentration on space and unhousing, later claiming that Cordelia's 'nothing' 'guarantees' his conclusions (32). There are two problems, however. Firstly, Lear is talking to Kent in the line Estok quotes: the subversion of authority of which Lear complains is in the previous line - Kent has 'come betwixt our sentence and our power'. Lear's anger is not directed at silence, but at speech. Secondly, Lear's 'place' - which Estok wants to mean 'space' - is clearly the hierarchical place of his social rank: place as in 'Position or standing in an order of estimation or merit; spec. a person's social rank or status; the duty or rights appropriate to a social rank.' (OED 'place' 15a). The basis for the argument Estok makes may be elsewhere in the play, but it is not in that line, which he treats as pivotal.

${ }^{4}$ It should be emphasised that although I have placed Estok and Egan in the same section - I have done so for their shared presentist emphasis - neither would thank me for the association. Estok contends that Egan's Green Shakespeare 'fails at fully comprehending either the history or the goals of ecocritical theory' and that it 'virtually ignores ecocriticism' (Ecocriticism 12, 11, Estok's emphasis). (As with accusations of 'not really ecocriticism' (see above 00), the claim that a work under review ignores ecocriticism has long been a favourite one among some ecocritics). Egan, meanwhile, calls Estok's work 'execrable', in part for its 'crude misreadings' (along the lines of those I have noted above), and claims that it 'makes no concessions to...traditional criticism' (Ecocritical 31).

${ }^{5}$ Although his historicism doesn't extend to Erasmus, whose De Copia would have informed his understanding of fishmongers, as it apparently informed Shakespeare's. See, for example, Skinner 233.

${ }^{6}$ See Woods 246-257.

${ }^{7}$ For details on this oceanic turn, see Mentz, Ocean 101-106. See also PMLA and Publicover.

${ }^{8}$ Watson's 'intelligent work' here is, perhaps, an instance of 'presentists [being] coded as unscholarly', that O'Dair argues forcefully against ('Presentist' 75). 
${ }^{9}$ For a work that discusses environmental theatre history and makes an explicit case for historicist ecocriticism, albeit without open advocacy, see Gwilym Jones's Shakespeare's Storms (2015). For a more overtly ecocritical reading of Shakespeare's storms, focusing on King Lear, see Mentz 'Strange'. For a reading tracing Lear's storm in performance across the centuries, see Jennifer Hamliton.

${ }^{10}$ The exceptions mentioned tend to focus on the experience of the Little Ice Age. See for example, Robert Markley, 'Summer's Lease: Shakespeare in the Little Ice Age' (in Hallock et al, 131-142).

${ }^{11}$ See, for example, Martin Knoll and Reinhold Reith (2014) for recent developments.

${ }^{12}$ Environmental History maintains a database of new scholarship in the field. http://published-sources.environmentalhistory.net/ 


\section{Works Cited}

Aberth, John. An Environmental History of the Middle Ages: The Crucible of Nature. New York: Routledge, 2012.

Arch, Jakobina Kirsten. 'Bringing Whales Ashore: Oceans and the Environment of Early Modern Japan, 1600-1900.' Diss. Harvard, 2014.

Arons, Wendy and Theresa J. May, eds. Readings in Performance and Ecology. New York: Palgrave Macmillan, 2012.

Barnes, Jay. North Carolina's Hurricane History. Chapel Hill: U of North Carolina Press, 2013.

Boehrer, Bruce. Environmental Degradation in Jacobean Drama New York: Cambridge University Press, 2013.

Bolster, W. Jeffrey. The Mortal Sea: Fishing the Atlantic in the Age of Sail. Cambridge, MA: Belknap Press of Harvard UP, 2012.

Borlik, Todd. Ecocriticism and Early Modern English Literature: Green Pastures. New York: Routledge, 2011.

Borlik, Todd. 'Caliban and the Fen Demons of Lincolnshire: the Englishness of Shakespeare's Tempest.' Shakespeare 9 (2013): 21-51.

Brayton, Dan. Shakespeare's Ocean: An Ecocritical Exploration. Virginia: U of Virginia Press, 2012.

Bruckner, Lynne, and Dan Brayton, eds. Ecocritical Shakespeare. Farnham and Burlington: Ashgate, 2011

Buell, Lawrence. The Future of Environmental Criticism: Environmental Crisis and Literary Imagination. Oxford: Blackwell, 2005.

Degroot, Dagomar. "Never Such Weather Known in These Seas": Climatic Fluctuations and the Anglo-Dutch Wars of the Seventeenth Century, 1652-1674.' Environment and History 20 (May 2014): 239-273.

De Kraker, Adriaan. 'Storminess in the Low Countries, 1390-1725.' Environment and History 19 (May 2013): 149-171.

DiPietro, Cary, and Hugh Grady, eds. Shakespeare and the Urgency of the Now: Criticism and Theory in the $21^{\text {st }}$ Century. Basingstoke: Palgrave Macmillan, 2011.

Egan, Gabriel. Shakespeare and Ecocritical Theory. London: Bloomsbury Arden Shakespeare, 2015.

Estok, Simon C. Ecocriticism and Shakespeare: Reading Ecophobia. Basingstoke: Palgrave Macmillan, 2011. 
Estok, Simon C. 'Afterword: Ecocriticism on the Lip of a Lion.' Ecocritical Shakespeare. Eds. Lynne Bruckner and Dan Brayton. Farnham and Burlington: Ashgate, 2011. 239_ 246.

Evelyn, John. Fumifugium, or the Inconvenience of the Aer and Smoak of London Dissipated. London: W. Godbid for Gabirel Bedel and Thomas Collins, 1661.

Feerick, Jean E., and Vin Nardizzi, eds. The Indistinct Human in Renaissance Literature. New York: Palgrave Macmillan, 2012.

Galloway, James A. 'Coastal Flooding and Socioeconomic Change in Eastern England in the Later Middle Ages.' Environment and History 19 (May 2013): 173-207.

Garrard, Greg. 'Introduction.' The Oxford Handbook of Ecocriticism. Ed. Greg Garrard. Oxford: OUP, 2014. 1-26.

Gifford, Terry. Pastoral. London: Routledge, 1999.

Grandjean, Katherine A. 'New World Tempests: Environment, Scarcity, and the Coming of the Pequot War.' William and Mary Quarterly 68 (January 2011): 75-100.

Grossman, Joanna. 'Timon of Ashes' Journal of Ecocriticism 6.2 (2014): 1-20.

Hallock, Thomas, Ivo Kamps, and Karen L. Raber eds. Early Modern Ecostudies: From the Florentine Codex to Shakespeare New York: Palgrave Macmillan, 2008. 11-30.

Hamilton, Jennifer Mae. " "What is the Cause of Thunder?” A Study of the Storm in King Lear.' Diss. U of New South Wales, 2012.

Headrick, Daniel R. Powver over Peoples: Technology, Environments, and Western Imperialism, 1400 to the Present. Princeton: Princeton UP, 2012.

Heise, Ursula. 'The Hitchhiker's Guide to Ecocriticism.' PMLA 121.2 (2006): 503-16.

Hiltner, Ken. What Else is Pastoral?: Renaissance Literature and the Environment. Ithaca, NY: Cornell UP, 2011.

Hoffmann, Richard C. An Environmental History of Medieval Europe. New York: Cambridge UP, 2014.

Jones, Gwilym. Shakespeare's Storms. Manchester: Manchester UP, 2015.

Kiser, April M. 'Making True and Lively Figures: Early Modern Natural History Images and the Transformations of Nature.' Diss. State U New York at Buffalo, 2011.

Knight, Leah. Reading Green in Early Modern England. Farnham and Burlington: Ashagate, 2014.

Knoll, Martin and Reinhold Reith, eds. An Environmental History of the Early Modern Period: Experiments and Perspectives. Zürich and Berlin: Lit Verlang, 2014. 
Macdonald, Alan R., and John McCallum. 'The Evidence for Early Seventeenth-Century Climate from Scottish Ecclesiastical Records.' Environment and History 19 (November 2013): 487-509.

MacFaul, Tom. Shakespeare and the Natural World. Cambridge: CUP, 2015.

Mackenzie, Louisa, and Stephanie Posthumus. 'Reading Latour Outside: A response to the Estok-Robisch Controversy.' ISLE 20.4 (2013): 757-77.

Manwood, John. A Treatise and Discource of the Lawes of the Forrest. London: Thomas Wight and Bonham Norton, 1598.

Marland, Pippa. 'Ecocriticism.' Literature Compass, 10 (2013): 846-868.

Martin, Randall. Shakespeare and Ecology. Oxford: OUP, 2014.

McColley, Diane. Milton's Eve. Urbana IL, U of Illinois Press, 1983.

Mentz, Steve. At the Bottom of Shakespeare's Ocean. London: Continuum Press, 2009.

Mentz, Steve. “Strange Weather in King Lear.” Shakespeare 6:2 (2010): 139-52.

Mentz, Steven. "Toward a Blue Cultural Studies: The Sea, Maritime Culture, and Early Modern English Literature.” Literature Compass 6:5 (2009): 997-1013.

Morton, Timothy. Ecology Without Nature: Rethinking Environmental Aesthetics. Cambridge, MA: Harvard UP, 2007.

Morton, Timothy. The Ecological Thought. Cambridge, MA: Harvard UP, 2010.

Munroe, Jennifer, Edward J. Geisweidt and Lynne Bruckner, eds. Ecological Approaches to Early Modern English Texts. Farnham and Burlington, VT: Ashgate, 2015.

Munroe, Jennifer, and Rebecca Laroche, eds. Ecofeminist Approaches to Early Modernity. New York: Palgrave Macmillan, 2011.

Nardizzi, Vin. Wooden Os: Shakespeare's Theatres and England's Trees. Toronto, Buffalo and London: U of Toronto Press, 2013.

O'Dair, Sharon. 'The State of the Green: A Review Essay on Shakespearean Ecocriticism.' Shakespeare 4.4 (2008): 459-77.

O'Dair, Sharon. 'Slow Shakespeare: An Eco-Critique of "Method" in Early Modern Studies.' Early Modern Ecostudies: From the Florentine Codex to Shakespeare, eds. Thomas Hallock, Ivo Kamps, and Karen L. Raber. New York: Palgrave Macmillan, 2008. 11-30.

O'Dair, Sharon. 'Is it Shakespearean Criticism if it isn't Presentist?' Ecocritical Shakespeare. Eds. Lynne Bruckner and Dan Brayton. Farnham and Burlington: Ashagate, 2011. 7185. 
O'Malley, Evelyn. The Natural Place for the Play: Outdoor Shakespeare, Environment, and an Ethnography of Audience Experience. Diss. U of Exeter, 2016.

PMLA 125.3 (2010): 657-736. Special issue on Oceanic Studies.

Publicover, Laurence. 'Shakespeare at Sea.' Essays in Criticism 64.2 (2014): 138-157.

Raber, Karen. 'Recent Ecocritical Studies of English Renaissance Literature.' English Literary Renaissance 37.1 (2007): 151-71.

Richards, John. The Unending Frontier: An Environmental History of the Early Modern World (2003).

Robisch, S.K. 'The Woodshed: A Response to Ecocriticism and Ecophobia.' ISLE 16.4 (2009): 697-708.

Rohr, Christian. 'Floods of the Upper Danube River and Its Tributaries and Their Impact on Urban Economies (c. 1350-1600): The Examples of the Towns of Krems/Stein and Wels (Austria).' Environment and History 19 (May 2013): 133-48.

Scott, Charlotte. Shakespeare's Nature: From Cultivation to Culture. Oxford: OUP, 2014.

Skinner, Quentin. Forensic Shakespeare. Oxford: OUP, 2014.

Soens, Tim. 'Threatened by Sea, Condemned by Man? Flood Risk and Environmental Inequalities along the North Sea Coast, 1200-1800.' Environmental and Social Justice in the City: Historical Perspectives. Ed. Genevieve Massard-Guilbaud and Richard Rodger. Cambridge: White Horse Press, 2011. 92-111.

Soens, Tim. 'Flood Security in the Medieval and Early Modern North Sea Area: A Question of Entitlement?' Environment and History 19 (May 2013): 209-232.

Taylor, Gail Marlow. 'Putting Down Roots: The Reception of New World Medicinal Plants in Early Modern Germany, 1492-1648.' Diss. U of California, Irvine, 2014.

Theis, Jeffrey. Writing the Forest in Early Modern England: A Sylvan Pastoral Nation. Pittsburgh: Duquesne UP, 2009.

Topsell, Edward. The Historie of Foure-Footed Beastes. London: William Jaggard, 1607.

Topsell, Edward. The Historie of Serpents or the Second Booke of Lining Creatures. London: William Jaggard, 1608.

Tyron, Thomas. The Way to Health, Long Life and Happiness. London: R. Norton, 1697.

Watson, Robert. Back to Nature: The Green and the Real in the Late Renaissance. Philadelphia: U of Pennsylvania Press, 2006.

Watson, Robert. 'Shadows of the Renaissance.' The Oxford Handbook of Ecocriticism. Ed. Greg Garrard. Oxford: OUP, 2014. 40-60. 
Watson, Robert. 'The Ecology of Self in A Midsummer Night's Dream.' Ecocritical Shakespeare. Eds. Lynne Bruckner and Dan Brayton. Farnham and Burlington: Ashagate, 2011. 33-56.

Wilcher, Robert 'The Greening of Milton Criticism' Literature Compass 7 (2010): 1020 1034.

Woods, Penelope. Globe Audiences: Spectatorship and Reconstruction at Shakespeare's Globe Diss. Queen Mary, U of London, 2012.

Zalasiewicz, Jan, and Mark Williams. The Goldilocks Planet: The Four Billion Year Story of Earth's Climate. New York: OUP, 2012. 